\title{
Immunohistochemical Distribution of Calcium Binding Proteins in the Cochlear Nuclear Complex of Circling Mice
}

\author{
Distribución Inmunohistoquímica de Proteínas de Unión a Calcio \\ en el complejo Nuclear Coclear de Ratones Circulantes
}

Ji Ho Ryu1; Jonu Phradhan²; Myeung Ju Kim³ \& Dhiraj Maskey ${ }^{4}$

RYU, J. H.; PHRADHAN, J.; KIM, M. J. \& MASKEY, D. Immunohistochemical distributionof calcium binding proteins in the cochlear nuclear complex of circling mice. Int. J. Morphol., 39(2):538-547, 2021.

SUMMARY: The term "circling mouse" refers to an animal model of deafness, in which the mouse exhibits circling, head tossing, and hyperactivity, with pathological features including degenerated spiral ganglion cells in the cochlea, and the loss of the organ of Corti. The cochlear nuclear $(\mathrm{CN})$ complex, a part of the auditory brain circuit, is essential to process both ascending and descending auditory information. Considering calcium's $\left(\mathrm{Ca}^{2+}\right)$ importance in homeostasis of numerous biological processes, hearing loss by cochlear damage, either by ablation or genetic defect, could cause changes in the $\mathrm{Ca}^{2+}$ concentration that might trigger functional and structural alterations in the auditory circuit. However, little is known about the correlation of the central nervous system (CNS) pathology in circling mice, especially of the auditory pathway circuit and $\mathrm{Ca}^{2+}$ changes. This present study investigates the distribution of $\mathrm{Ca}^{2+}$ binding proteins (CaBPs), calbindin D-28k (CB), parvalbumin (PV), and calretinin (CR) by using a free floating immunohistochemical method inthe $\mathrm{CN}$ of the wild-type mouse $(+/+)$, the heterozygous mouse $(+/$ cir $)$, and the homozygous $($ cir/cir) mouse. CaBPs are well known to be an important factor that regulates $\mathrm{Ca}^{2+}$ concentrations. Compared with the dorsal and ventral cochlear nuclei of $+/+$ and $+/$ cirmice, prominent decreases of CaBPs' immunoreactivity (IR) in cir/cirmice were observed in the somas, as well as in the neuropil. The present study reportson the overall distribution and changes in the immunoreactivity of CaBPs in the CN of cir/cirmice because ofa hearing defect. This data might be helpful to morphologically elucidate CNS disorders and their relation to CaBPs immunoreactivity related to hearing defects.

KEY WORDS: Calretinin; Calbindin D28-k; Cochlear Nuclear Complex; Circling mouse; Parvalbumin.

\section{INTRODUCTION}

The circling mouse (C57BL/6J-cir), an animal model for deafness arising because of a spontaneous mutation in the circling gene mapped to $60.1 \mathrm{cM}$ on chr 9 , is transmitted with $100 \%$ penetrance and inherited in an autosomal recessive mode (Lee et al., 2002). The cir/cir mouse exhibits circling behavior, head tossing, and hyperactivity with pathological findings, showing degenerated spiral ganglion cells in the cochlea (Cho et al., 2003, 2006).

The cochlear nuclear complex, the first station of the auditory brain stem circuit, possesses distinct activity properties that process both ascending and descending auditory information. The $\mathrm{CN}$ is composed of the dorsal cochlear nucleus (DCN) and the ventral cochlear nucleus
(VCN), with further division of VCN into anteroventral $(\mathrm{AVCN})$ and posteroventral $(\mathrm{PVCN})$ divisions. Specific cell types within the $\mathrm{CN}$ receive morphologically distinct axosomatic endings of primary afferent fibers from cochlea (Ryugo \& Parks, 2003) and are highly vulnerable to pathological alterations from the peripheral organ. In turn, the fibers from the cells of the cochlear nuclei form parallel ascending pathways to the superior olivary complex (SOC) for processing different features of sound (Cant \& Benson, 2003). Hearing loss induced by unilateral/bilateral cochlear ablation in neonatal rat pups has been reported to disrupt the development of afferent projections in the brainstem circuit (Franklin et al., 2006, 2008) whereas loss of cochlear integrity has resulted in various morphological, biochemical

\footnotetext{
${ }^{1}$ Department of Emergency Medicine, Pusan National University Yangsan Hospital, School of Medicine, Pusan National University, Yangsan, South Korea.

${ }^{2}$ Faculty of Medicine, School of Biomedical Sciences, The University of Queensland, Brisbane, QLD, Australia.

${ }^{3}$ Department of Anatomy, Dankook University College of Medicine, Cheonan-si, Chungcheongnam-do, South Korea.

${ }^{4}$ NeuroVIS, \#110, Jiksan-ro, Cheonan-si, Chungcheongnam-do, South Korea.
} 
and metabolic changes throughout the auditory system (Syka, 2002).

Maintenance of structural and functional integrity of the neurons in the auditory brainstem nuclei is dependent upon auditory input with sensory deprivation, leading to alterations in physiology, morphology, and metabolism of the auditory neurons (Rubel et al., 1990). Ablation of the cochlea early in postnatal development has shown severe effects on the auditory nuclei, with a reduction, or even the absence of structural plasticity (Mostafapour et al., 2000, 2002). Hearing loss due to cochlear ablation suggests that cellular factors might influence functional and structural alterations of the auditory circuit (Illing, 2001; Syka), with $\mathrm{Ca}^{2+}$ concentration being one such possible cellular factor. Having the highest rates of activity in the CNS, the proper functioning of the auditory neurons also depends upon the maintenance of $\mathrm{Ca}^{2+}$ homeostasis. Activity deprivation through afferent input removal has been reported to increase intracellular concentration (Zirpel et al., 1995). These are indications that the auditory neurons are unable to maintain $\mathrm{Ca}^{2+}$ homeostasis because ofa pathological increase in intracellular $\mathrm{Ca}^{2+}$ concentration.

$\mathrm{Ca}^{2+}$ is a major moderator of a number of essential physiological processes such as neuronal excitability, synthesis and a release of neurotransmitters, axonal transport, or membrane permeability (Yew et al., 1997). Neurons possess specialized homeostatic mechanisms to ensure a tight command of cytosolic $\mathrm{Ca}^{2+}$ levels controlling both the intracellular levels, as well as the location of $\mathrm{Ca}^{2+}$. It does this through a complex interplay between $\mathrm{Ca}^{2+}$ influx and efflux and $\mathrm{Ca}^{2+}$ buffering and internal $\mathrm{Ca}^{2+}$ storage (Arundine $\&$ Tymianski, 2003). Excessive $\mathrm{Ca}^{2+}$ influx or release from intracellular stores might elevate the calcium loads, exceeding its regulatory mechanisms' capacity. This can lead to an inappropriate activation of $\mathrm{Ca}^{2+}$-dependent processes, causing metabolic derangements and eventual cell death (Krebs, 1998). Therefore, the efficient regulation of the intracellular free $\mathrm{Ca}^{2+}$ concentration is vital for neuronal function and survival.The active uptake mechanism of the cell's internal membrane structures, such as the mitochondria and the endoplasmatic reticulum, as well as the CaBPs, can achieve this.

$\mathrm{CaBPs}$ responsible for $\mathrm{Ca}^{2+}$ buffering are expressed abundantly and are distributed in morphologically distinct cells and fibers in the auditory system nuclei (Caicedo $e t$ al., 1997; Idrizbegovic et al., 2001). Parvalbumin is present in most auditory nuclei (Lohmann \& Friauf, 1996). CB (Friauf, 1994) and CR (Winsky \& Jacobowitz, 1995) have been localized to particular subsets of the auditory neurons. The role of these proteins in $\mathrm{Ca}^{2+}$-dependent mechanisms during development (Lohmann \& Friauf), both neural (Caicedo et al., 1996) and in response to deafferentation (Alvarado et al., 2004), have been studied. They appear to play a role in the control of $\mathrm{Ca}^{2+}$ homeostasis by buffering the $\mathrm{Ca}^{2+}$ that enters the cells during synaptic activation (Baimbridge et al., 1992). Nevertheless, the precise role of $\mathrm{CaBPs}$ in modulating the $\mathrm{Ca}^{2+}$-mediated effects of neuronal activity and synaptic plasticity in the $\mathrm{CN}$ is still unclear. With auditory neurons having among the highest rates of activity in the CNS, their proper function depends on the maintenance of $\mathrm{Ca}^{2+}$ homeostasis (Hack et al., 2000). Therefore, $\mathrm{Ca}^{2+}$ homeostatic alteration in the $\mathrm{CN}$ possibly effecting the neuronal activity and synaptic plasticity may be responsible for the characteristic features of circling mice. Thus, the present study, uses immunohistochemistry to compare CB, $\mathrm{PV}$ and $\mathrm{CR}$ immunoreactivity in the cochlear nuclei of the $+/+$, the $+/$ cir, and the cir/cir mice.

\section{MATERIAL AND METHOD}

Animals. Fifteen mice $(+/+, \mathrm{n}=5 ;+/ \mathrm{cir}, \mathrm{n}=5$; and $\mathrm{cir} / \mathrm{cir}, \mathrm{n}=5)$ were used in the present study and were kept under controlled conditions (ambient temperature of $20-25^{\circ} \mathrm{C}, 12$-hour light/ dark cycle) with an ad libitum supply of food and water. We followed both the NIH guidelines of animal research and 'Dankook University Institutional Animal Care and Use Committee' (DUIAC), which adheres to the guidelines issued by the Institution of Laboratory of Animal Resources (ILAR).All surgery was performed under sodium pentobarbital anesthesia and every effort was made to minimize suffering.

Polymerase Chain Reaction. Cir/cir males were mated with $+/$ cir to produce $+/$ cirandcir/cir mice on postnatal day 16 (P16). To prevent genetic mixing, both $+/$ cir and cir/cir mice were completely separated from $+/+$ mice. We did a polymerase chain reaction (PCR) analysis to separate the + / cir and thecir/cir mice, using genomic DNA collected from the mouse tails. We isolated the genomic DNA according to the manufacturer's instructions (Bioneer Corporation, Daejeon, South Korea). The cir/cir mouse was identified by the absence of the TMIE gene (Chung et al., 2007). We did a PCR, using primers designed to amplify the exon 1 coding part of the TMIE gene (forward, 5' AGCTGTAGCTCTGAAATCT 3'; reverse, 5' TCTGGCAGAATGCATGGAGGCT 3') in accordance with the earlier method (Chung et al.).

Immunohistochemistry. Mice were deeply anesthetized and perfused transcardially with cold phosphate buffer $(0.1 \mathrm{M}$ PBS [pH 7.4]), followed by cold $4 \%$ paraformaldehyde 
(PFA) in $0.1 \mathrm{M}$ of PBS. The brains were post fixed overnight in PFA, cryoprotected in a series of sucrose solutions, and sectioned coronally at $40 \mu \mathrm{m}$ thickness. Immunohistochemistry was performed in accordance with the freefloating method described earlier (Maskey et al., 2010), with polyclonal rabbit CB (1:5,000, AB1778; Millipore, CA, USA), polyclonal anti-rabbit PV (1:10,000, PV 25; Swant, Bellinzona, Switzerland), and polyclonal anti-goat CR $(1: 15,000$, AB1550; Millipore, CA, USA) antibodies in a blocking buffer ( $2 \%$ bovine serum albumin, $0.3 \%$ Triton $\mathrm{X}-100,1 \%$ horse serum, and 0.1M PBS). Following 48 hours of incubation, the sections were washed and incubated in biotinylated anti-rabbit and anti-goat $\operatorname{IgG}$ at a dilution ratio of 1:250, then treated it with an avidin-biotin-peroxidase complex (VECTASTAIN®ABC mouse Elite Kit; Vector Laboratories, CA, USA). The reaction was visualized using a solution containing $0.0125 \%$ diaminobenzidine, mounted on gelatin-coated slides, dehydrated, and cover-slipped. To eliminate conflicts, we conducted simultaneous section staining from each group. We did a negative control study by omitting primary antiserum.

Image analysis and Statistical analysis. We evaluated the stained sections with an Olympus BX51 microscope, and we took pictures of the sections with a microscope digital camera system (BX51; Olympus, Japan). The images were obtained at 600 dpi (1890 X 2612 pixel) with 8 bit depth. We determined staining densities with the NIH image program (Scion Image, Bethesda, Maryland, USA), as described previously (Maskey et al.). The sum of the gray values of all pixels in each corresponding area was divided by the total number of pixels in the region to determine the mean density of immunoreactivity (IR) per unit area (mm2 ). The results are expressed as a mean $\pm \mathrm{SD}$, analyzed with a one-way analysis of variance by using the GraphPad Prism Software (GraphPad Software, Inc., USA, Ver 5.01), followed by Bonferroni's post-hoc test. We deemed a $\mathrm{P}<0.05$ to be statistically significant.

\section{RESULTS}

Distribution of CB IR was observed throughout the cochlear nuclear complex with varying intensity. The most conspicuous population of $\mathrm{CB}$ immunoreactive neurons was observed in the AVCN and the PVCN, whereas DCN was almost devoid of CB immunoreactive neurons in any of the three groups (Fig. 1 and 2). The outer cell layer of the AVCN did not show any cells (Fig. 1), but CB was widely distributed in the inner layer of the $+/+$, mainly comprised of globular and a few octopus cells (Fig. 1D). We observed the severe loss of CB immunoreactive cells in the AVCN region of cir/ cir (Fig. 1F). CB immunoreactive cells appear to decrease in number and staining intensity in the $+/$ cir and the cir/cir. In comparison with the $+/+$, severity in loss of cells and neuropil staining was much more prominent in the cir/cir than the +/cir (Fig. 1C and F), with very few scarcely-labeled, presumably stellate or cartwheel cells in the DCN, along with faint neuropil staining (Fig. 2G-I). Faintly labeled immunoreactive fibers encircling unlabeled cells could also be noted in all three groups (Fig. 2G-I). The CB PVCN immunoreactive neurons were distributed throughout the entire nucleus, excluding the outer cell layer, in all the three groups (Fig. 2D-F). The entire nucleus was mainly comprised of globular cells, which displayed varying staining intensities in the three groups (Fig. 2J-L). Numerous cells in the PVCN of the cir/cir mice displayed severe loss of CB IR, although it was clearly labeled in the $+/+$ and the $+/$ cir mice. Loss of
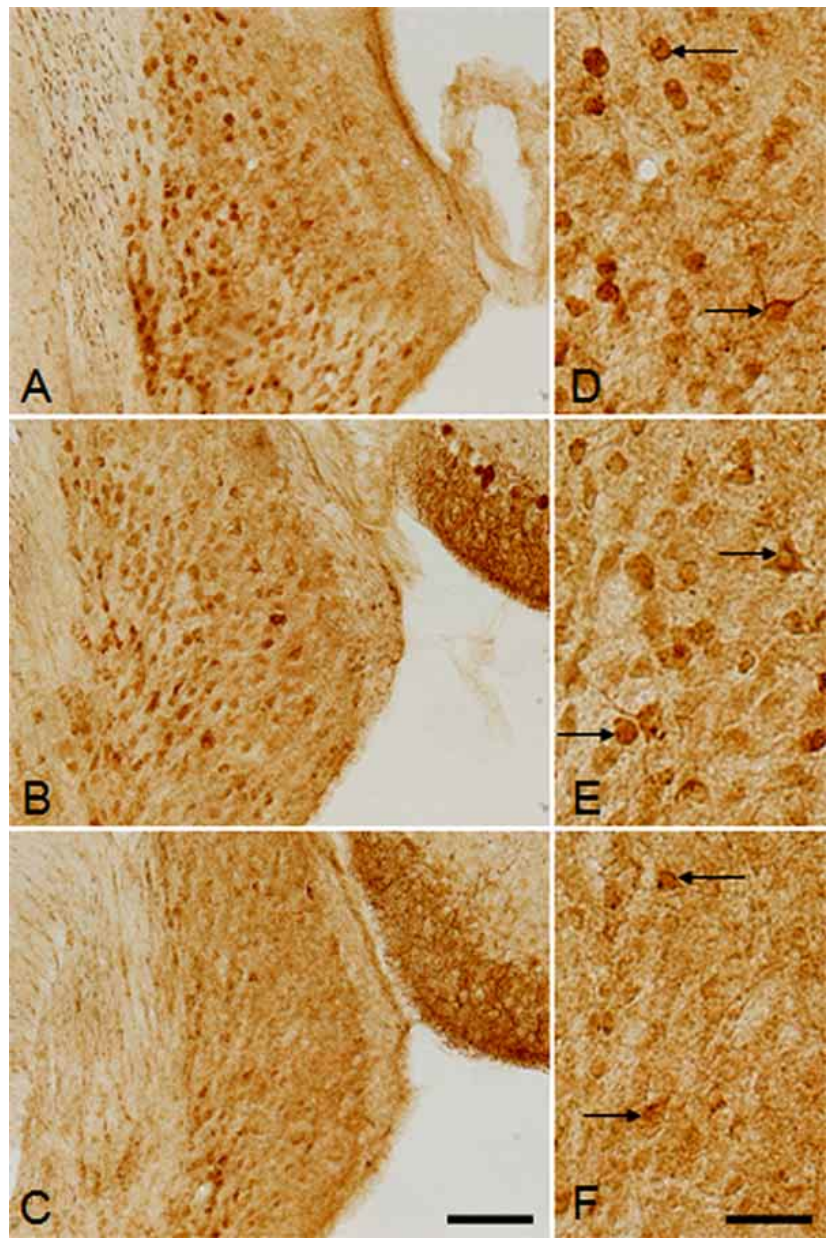

Fig. 1. Image displaying the distribution of calbindin D28-k (CB) immunoreactivity (IR) in coronal sections through the AVCN of P16 wild-type (+/+ mice) (A, D), heterozygous (+/cir mice) (B, E), and homozygous (cir/cir) (C, F) mice. The outer layer was devoid of cells whereas the inner layer showed numerous CB stained cells (arrows). Note the drastic loss of CB immunoreactive cells, as well as the neuropil IR in thecir/cirmice (F). Abr: AVCN, Anteroventral Cochlear Nucleus. Scale bar= A-C, $100 \mu \mathrm{m}$; D-F, $50 \mu \mathrm{m}$. 
both the neuropil, as well as neuronal staining, was visible in the cir/cir as compared to the $+/+$ mice (Fig. 2L).

We observed PV IR in the CN's neurons, as well as in the neuropil, of all the three groups. They had varying intensities (Fig. 3 and 4). Comparison between the three groups revealed a marked decrease in PV IR in the cir/cir as compared to the $+/+$. Almost all the AVCN cells of were PV immunoreactive (Fig. 3A-C). The most common cell type stain was oval/round in shape and was densely packed in the rostral region (Fig. 3D-F). Occasionally, a short dendrite appeared to be arising from the cell body. The IR of these cells appeared to be highest in $+/+$ and lowest in cir/cir, depicting the loss of IR (Fig. 3A-C). Very few cells located in the outer layer appeared to be stained, whereas the majority of the cells in the innermost layer of DCN did not show any staining with PV. These unstained cells were surrounded by immunoreactive fibers (Fig. 4G-I). The staining intensity appeared to be decreased in the cir/cir as compared to the + / + mice (Fig. 4A-C). The majority of the PVCN cells showed a PV IR with short stained dendrites. The cells were mostly globular, but a few multipolar cells were also found to be present (Fig. 4J-L). The staining intensity appeared to decrease in the cir/cir as compared to the $+/+$ and the $+/$ cir mice (Fig. 4D-F).

CR IR was observed to be distributed in all the $\mathrm{CN}$ nuclei in the somas and the neuropil (Fig. 5 and 6). The PVCN was the most intensely CR immunoreactive among the $\mathrm{CNs}$, whereas the $\mathrm{AVCN}$ region was mainly comprised of numerous unlabeled neurons that were commonly outlined by labeled axonal endings in all three groups (Fig. 5A-C).

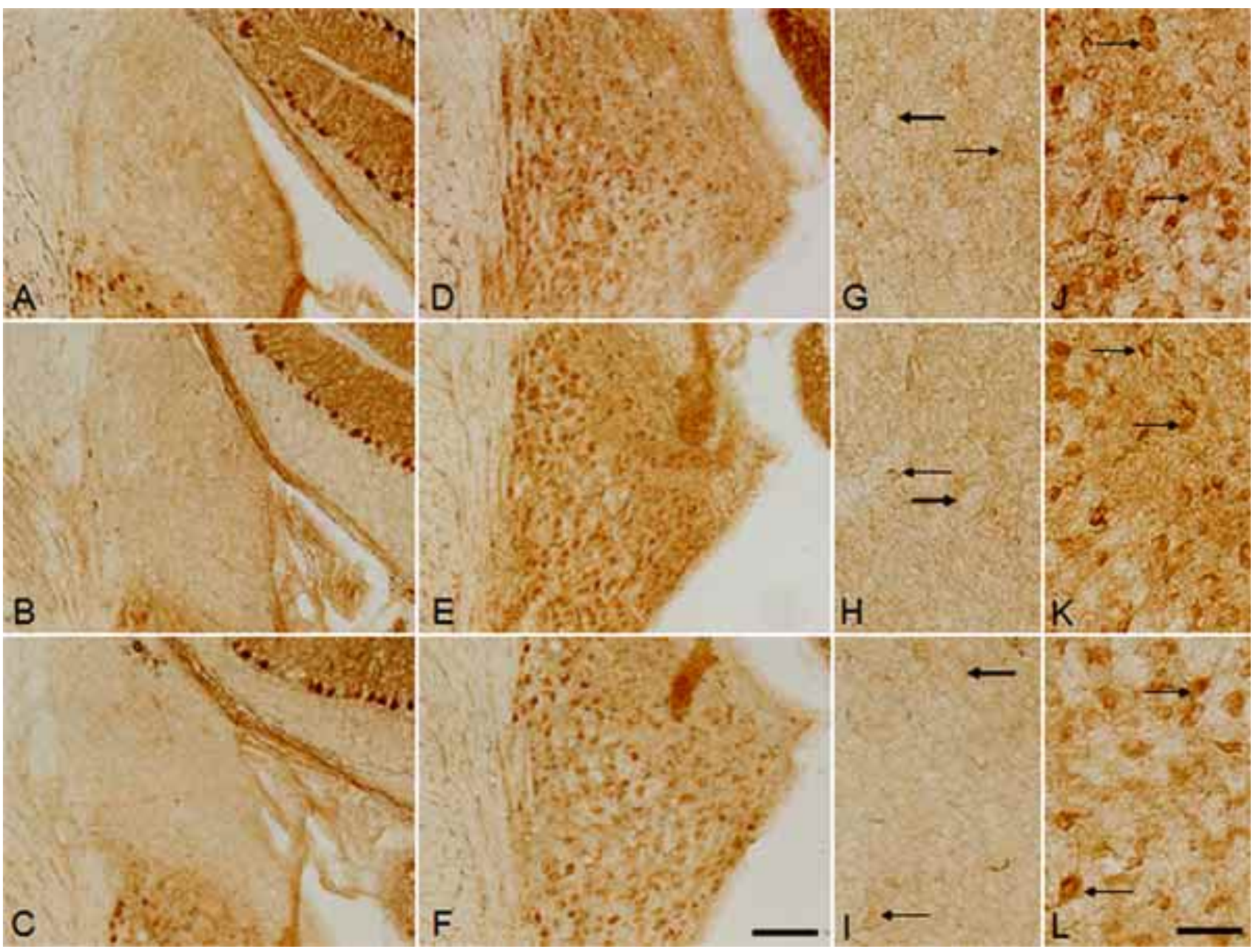

Fig. 2. Image displaying the distribution of calbindin D28-k (CB) immunoreactivity (IR) in coronal sections through the DCN (A-C, GI) and PVCN (D-F, J-L) of P16 wild-type (+/+) mice. (A, D, G, J), heterozygous (+/cir) mice (B, E, H, K), and homozygous (cir/cir) mice. (C, F, I, L) mice. Very faint labeling of the cells (thin arrows) was noted in the DCN (G-I), with a few immunoreactive fibers encircling the cells (thick arrows). Numerous highly CB immunoreactive cells (arrows) were noted in the PVCN (J-L) of all three groups,with varying intensity. Note the loss of IR in both the DCN and the PVCN of the cir/cir mice. Abr: DCN, Dorsal Cochlear Nucleus; PVCN,

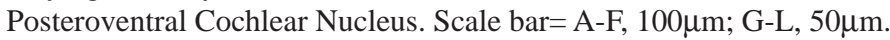




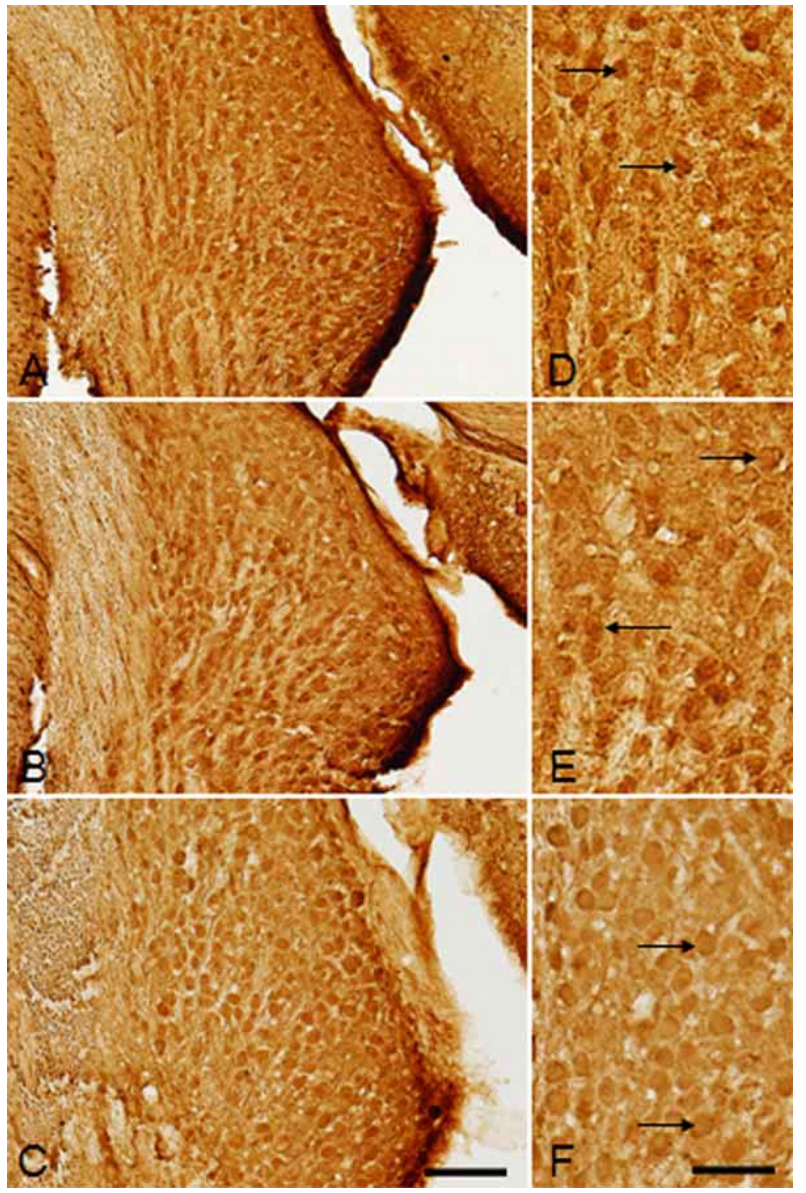

We saw a few darkly stained spherical cells in the innermost AVCN layer, which were darkly stained in the $+/+$ but appeared to lose staining intensity in the $+/$ cir and the cir/cir (Fig. 5DF). Although different cells types were stained, the current study did not list individual cell types in detail. The outer layer of the DCN was devoid of cells in all three groups, whereas the deeper layer was comprised of numerous cells of varying size and shape (Fig. 6A-C). The somas were small in size, very heavily $\mathrm{CR}$ immunoreactive, and mostly oriented in the rostral part of the deeper layer of DCN. The cir/cirmice displayed a conspicuous loss of such CR immunoreactive cells. We also noted CR immunoreactive fibers, mostly in the deeper layer of the $+/+$ and the $+/$ cir. But they appeared to decrease in staining intensity, as well as in number, in the cir/cir (Fig. 6GI). The DCN neuropil staining was lighter in comparison to the other nuclei (AVCN and PVCN). The PVCN displayed CR IR with varying intensities within the three groups. Most of the CR immunoreactive cells, probably octopus and globular, all having darker staining, were located in the deeper layer,

Fig. 3. Image displaying distribution of parvalbumin (PV) immunoreactivity (IR) in coronal sections through the AVCN of P16 wild-type (+/+) mice. (A, D), heterozygous (+/cir) mice (B, E), and homozygous (cir/cir) (C, F) mice. Almost all the cells appeared to be PV immunoreactive, which were oval or rounded in shape (arrows). Note short dendrites arising from the cells. Loss of IR in both cells, as well as the neuropil, was observed in the cir/ cir mice. Abr: AVCN, Anteroventral Cochlear Nucleus. Scale bar= A-C, $100 \mu \mathrm{m} ; \mathrm{D}-\mathrm{F}, 50 \mu \mathrm{m}$.
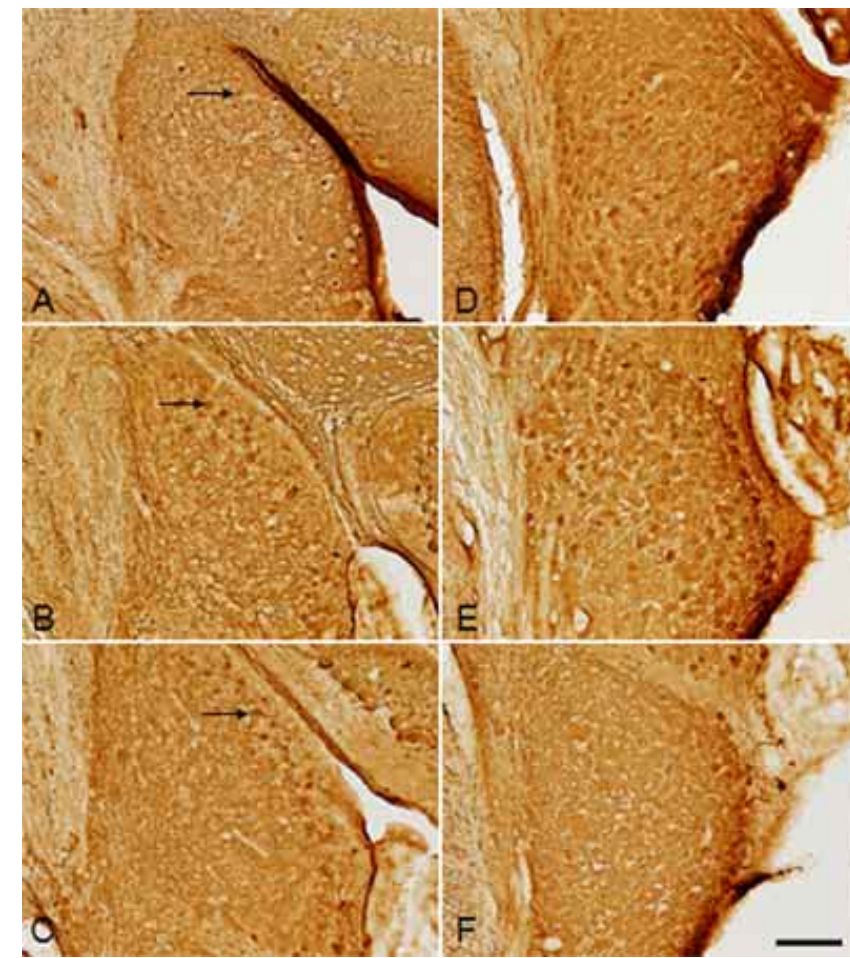

Fig. 4. Image displaying the distribution of parvalbumin (PV) immunoreactivity (IR) in the coronal sections through the DCN (A-C, G-I) and PVCN (DF, J-L) of the P16 wild-type (+/ $+)$ mice, $(\mathrm{A}, \mathrm{D}, \mathrm{G})$, heterozygous (+/cir) mice (B, E, H), and homozygous (cir/cir) mice (C, F, I). Outer layer of DCN (A-C) revealed few labeled cells (thin arrows) while the inner layer was devoid of such staining and surrounded by immunoreactive fibers (thin arrows) (G-I). A majority of the cells in the PVCN region (J-L) displayed short stained dendrites (thick arrows). Overall decrease in PV IR was noted in the cir/cir mice. Abr: DCN, Dorsal Cochlear Nucleus; PVCN, Posteroventral Cochlear Nucleus. Scale bar=A-

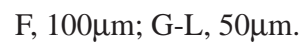




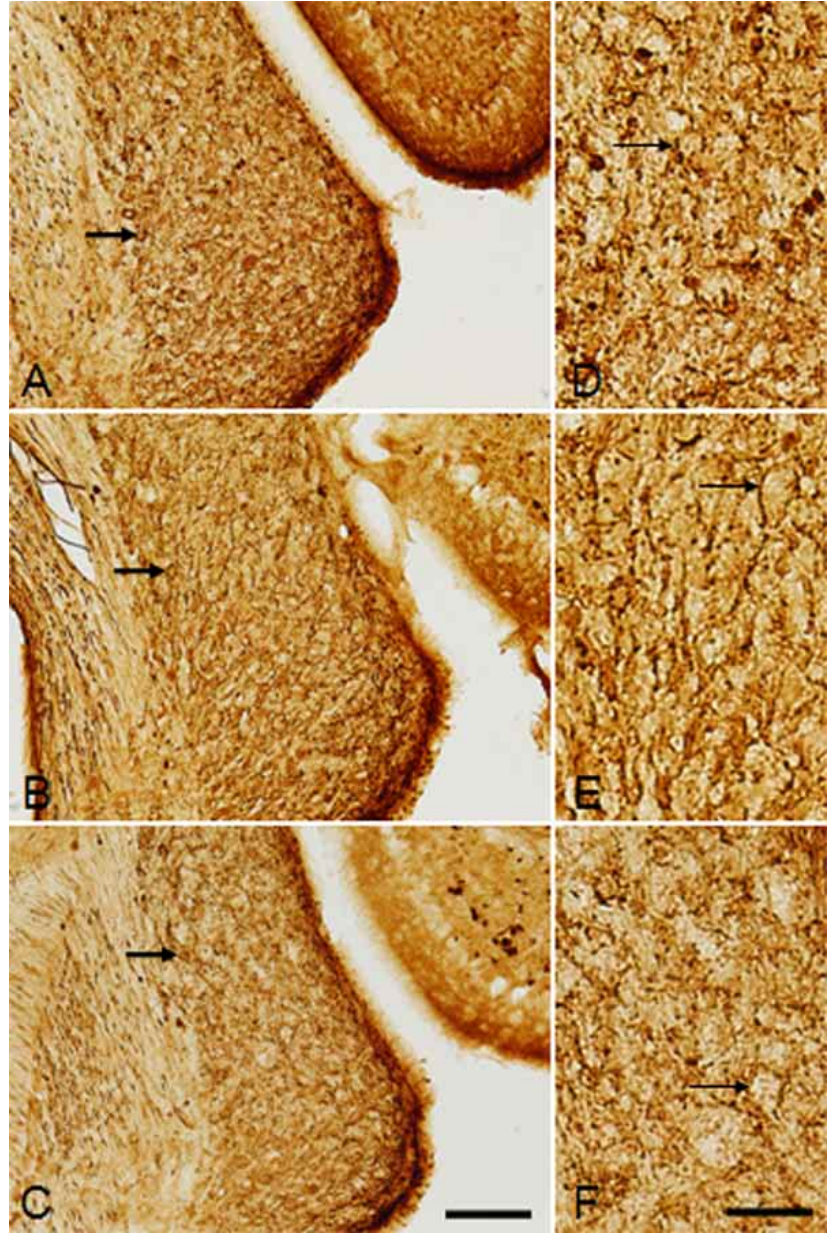

whereas the remaining cells appeared to be unstained (Fig. 6D-F). Such unstained cells appeared to be encircled by labeled CR immunoreactive fibers, probably axonal endings. Compared with the $+/+$ and the $+/$ cir mice, the cell IR, as well as the neuropil, appeared to be decreased in the cir/cir (Fig. 6J-L).

In the image analysis assessment, we measured the relative mean density of the different parts of the $\mathrm{CN}$ to compare the $\mathrm{CB}, \mathrm{PV}$, and CR IR distribution of the +/+ with the $+/$ cir and the cir/cir mice. The CB IR was observed to be lower in the DCN and PVCN nuclei of the $\mathrm{CN}$ region of the cir/cir than those of the $+/+$ or the $+/$ cir mice (Fig. 7A). Image analysis of the relative mean density revealed the highest PV IR to be present in the AVCN in all three groups and lowest in the DCN (Fig. 7B). However, no difference was noted between the $+/+$ and the $+/$ cir in any of the three nuclei regions. (Fig. 7B). The relative mean density analysis done to measure the CR IR in the $\mathrm{CN}$ revealed the highest CR IR to be present in the $+/+$, whereas the lowest was noted in cir/ cir mice in all three nuclei (Fig. 7C).

Fig. 5. Image displaying distribution of calretinin (CR) immunoreactivity (IR) in coronal sections through the AVCN of the P16 wild-type $(+/+)$ mice $(\mathrm{A}, \mathrm{D})$, heterozygous $(+/$ cir $)$ mice $(\mathrm{B}, \mathrm{E})$, and homozygous (cir/cir) (C, F) mice. Numerous unlabeled cells outlined by labeled axonal endings were noted (thin arrows). A few stained cells were also noted in the innermost layer of AVCN (thick arrows). Abr: AVCN, Anteroventral Cochlear Nucleus. Scale bar= A-C, $100 \mu \mathrm{m} ; \mathrm{D}-\mathrm{F}, 50 \mu \mathrm{m}$.

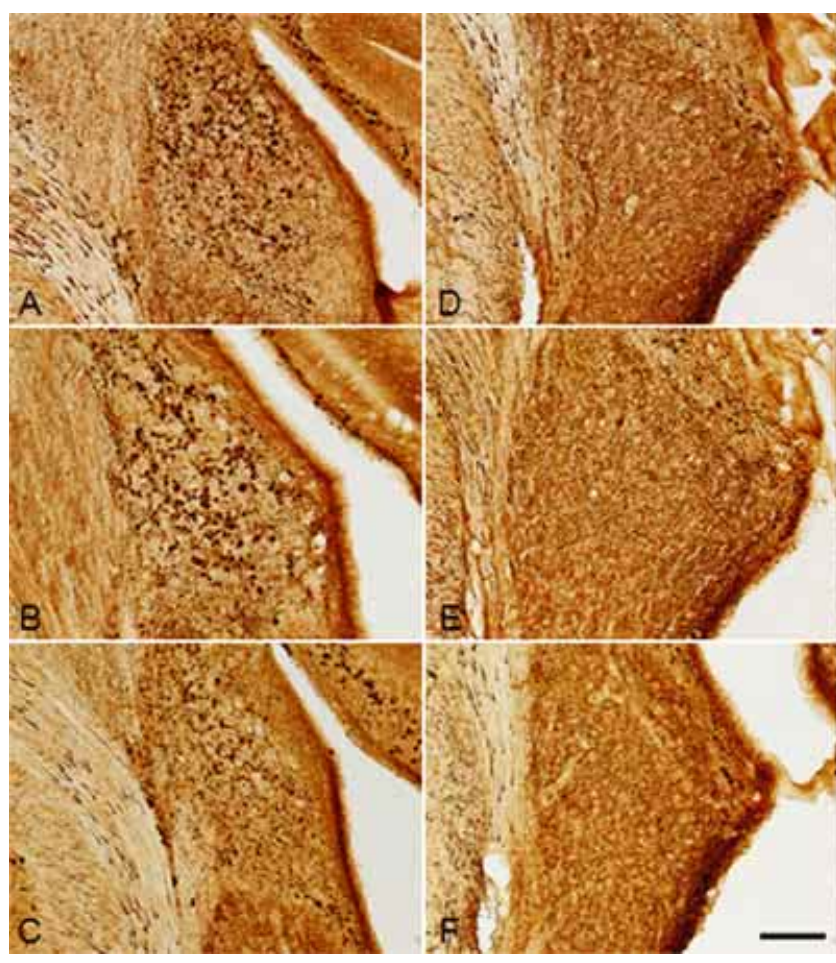

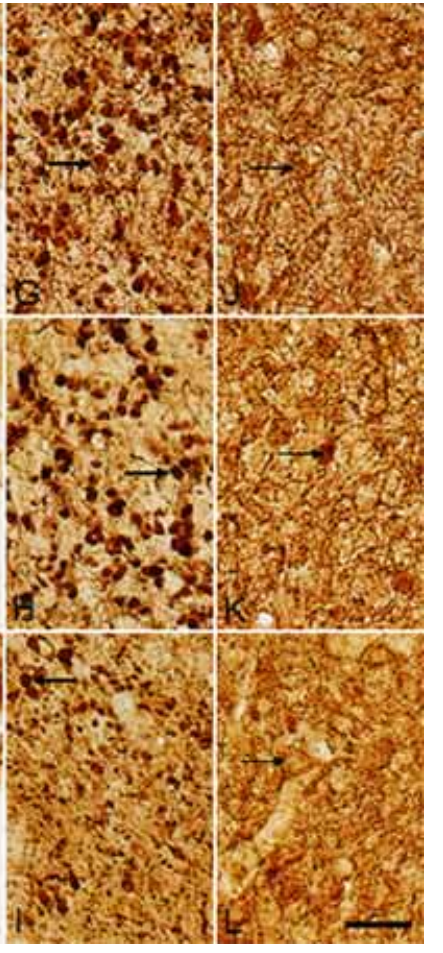

Fig. 6. Image displaying distribution of calretinin (CR) immunoreactivity (IR) in coronal sections through the DCN (A-C, G-I) and PVCN (D-F, J-L) of P16 wild-type (+/+) mice(A, D, G, J), heterozygous (+/cir)mice $(\mathrm{B}, \mathrm{E}$, $\mathrm{H}, \mathrm{K})$, and homozygous (cir/cir) (C, F, I, L) mice. Note the absence of cells in the outer layer of the DCN whereas the inner layer is comprised of numerous highly stained CR immunoreactive cells (thick arrows) of varying size. A prominent decrease in the number of such cells was noted in the cir/ cirmice. The PVCN also revealed numerous CR-positive cells (thin arrows) with varying intensities, which were observed to be lowest in the cir/cirmice. Abr: DCN, Dorsal Cochlear Nucleus; PVCN, Posteroventral Cochlear Nucleus. Scale bar=A-F, $100 \mu \mathrm{m}$; G-L, $50 \mu \mathrm{m}$. 


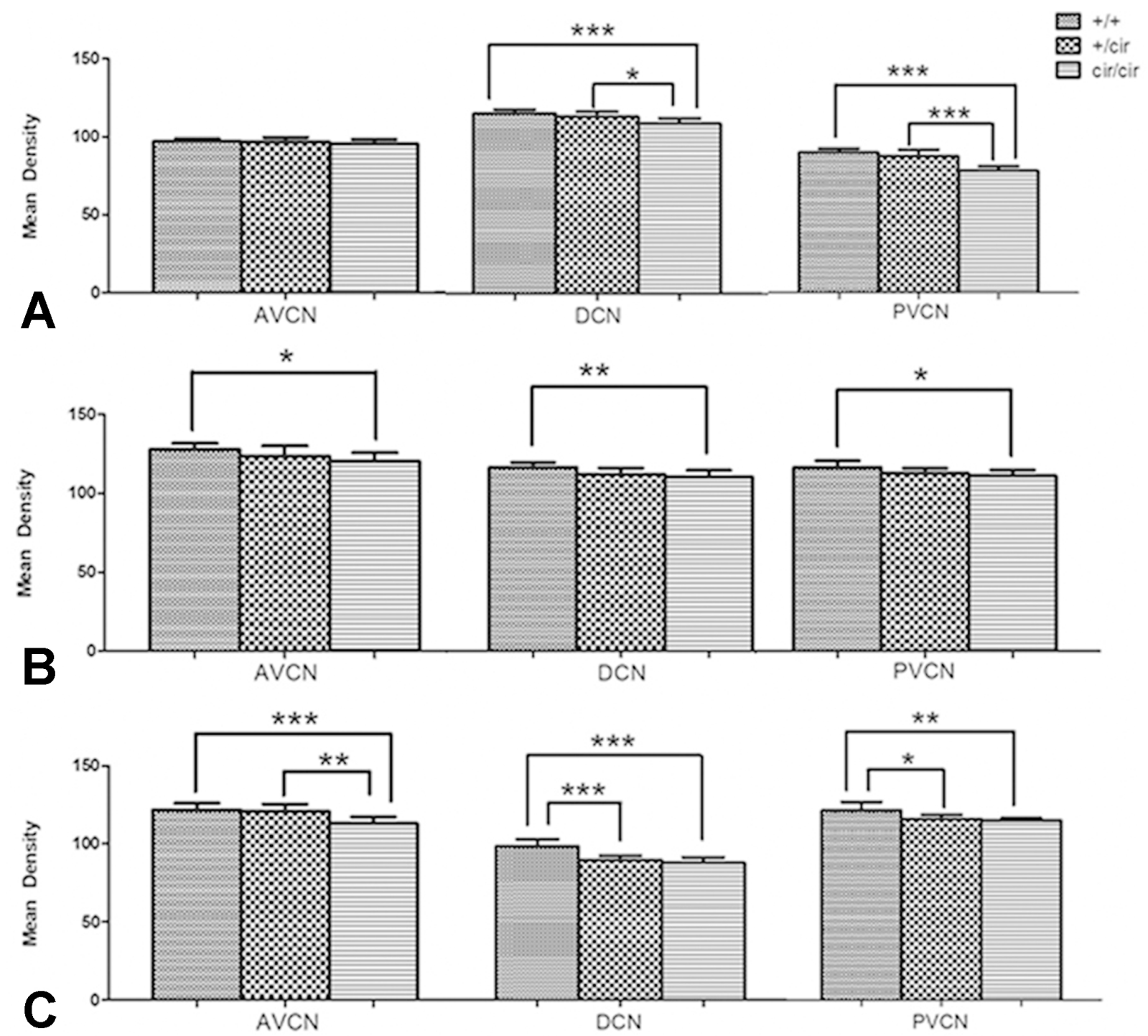

Fig. 7. Image analysis of the relative density of calbindin D28-k (A), parvalbumin (B), and calretinin (C) immunoreactivity (IR) changes in the cochlear nuclear complex (AVCN, DCN and PVCN) of the P16 wild-type (+/+) mice, heterozygous (+/ cir) mice, and homozygous (cir/cir) mice. Decrease in the IR was noted in cir/cirmice in various regions of the cochlear nuclear complex as compared to the $+/+$ mice. The data shown is a mean \pm SD obtained from three different experiments. Abr: AVCN, Anteroventral Cochlear Nucleus; DCN, Dorsal Cochlear Nucleus; PVCN, Posteroventral Cochlear Nucleus. $* \mathrm{p}<0.05, * * \mathrm{p}<0.01, * * * \mathrm{p}<0.0001$, compared with wild type mice.

\section{DISCUSSION}

The present study reports on the histomorphometric distribution of CaBPs (CB, PV and CR) in the $\mathrm{CN}$ and their relative density differences by comparing the $+/$ cir and the cir/cir with the+/+ to elucidate whether changes in the CaBPs' IR would be related to the characteristic features of the circling mouse. The IR of the CaBPs were substantially reduced in the cir/cir in almost all the nuclei as compared to the $+/+$, hinting at the possibility of a relationship between the reduction of CaBPs IR to the severity of the clinical symptoms of the cir/cir. The distribution of CaBPs in the cochlear nuclei of the $+/+$, the $+/$ cir and the cir/cir, as described in the present study, matched with the previous studies conducted in rats (Lohmann \& Friauf), mice (Idrizbegovic et al.), and ferrets (Alvarado et al., 2004). The CaBPs appeared to have a varying distribution in the AVCN, DCN and the PVCN parts of the cochlear nuclei in all three groups. We noted a significant decrement in all three CaBPs in the different parts of cochlear nuclei of the cir/cir, as 
compared to the $+/+$ and the $+/$ cir. The current study notes a decrease in the expression of CaBPs in the cir/ciras compared to the $+/+$. This depicts disturbances in the CaBPs IR following deafness.

The CB's role in the nerve cells is not well understood (Baimbridge et al.), but in the auditory system, it could be involved in monoaural processing (Zettel et al., 1991). We noted a prominent loss of $\mathrm{CB}$ immunoreactive cells in the AVCN and the PVCN part of cochlear nucleus in the cir/cir. This is likely due to the strong correlation between CB IR in the VCN and cochlear pathology, especially in the PVCN, as it receives the heaviest direct synaptic input from the auditory nerves (Harrison \& Irving, 1966; Kane, 1973). This is perfectly explained by the cochlear defect reported in the cir/cir. Hearing loss in the cir/cir could be related to a decrease of CB IR, with changes in auditory input. Disruption of inhibitory inputs into the cochlear nucleus due to cochlear pathology has resulted in changes in $\mathrm{CB}$ expression following unilateral cochleostomy (Förster \& Illing, 2000). Similar to this study, the cir/cir hearing loss model also presents with loss of the organ of Corti, which could be a contributing factor leading to loss of $\mathrm{CB}$ immunoreactive cells in the AVCN and the PVCN. The present finding is further supported by a study that depicts $\mathrm{Ca}^{2+}$ s $\mathrm{s}$ reducing and excitoprotective CB roles in cultured hippocampal neurons(Caicedo et al., 1997).

PV is believed to play an important role in central auditory processing (Caicedo et al., 1996; Lohmann \& Friauf). The PV IR was noted to be distributed in the auditory nuclei, which is in accordance with previous studies(Caicedo et al., 1996; Idrizbegovic et al.). The present study has noted a decrease in the PV IR in the cir/cirwhen compared to the $+/+$ in all parts of the cochlear nucleus. Previous study has reported an increase in PV IR with aging, along with loss of PV immunoreactive neurons (Idrizbegovic et al., 2001) that have been attributed to the activation of neurons that did not contain this protein at a young age. Changes in PV could be attributed to either severe progressive hearing loss or agerelated changes unrelated to auditory input. Unlike the present finding, the increased expression of other CaBPs have been reported following unilateral cochleostomy in rats (Förster \& Illing). However, such a phenomenon could be because of a rescue expression, as the total number of neuronal expressions has not been reported to be increased. Although no loss of neurons was noted in the present study, the PV IR appeared to be decreased in the cir/cir, which might indicate failure to counteract the increased intracellular $\mathrm{Ca}^{2+}$ concentration in neuronsbecause of cochlear defects in the cir/cir. The nonexistence of an increase in the PV IR in the cir/cir, unlike other studies, could be because of an almost total peripheral degeneration of the organ of Corti, which could affect it to a far greater extent. This could prevent the rescue expression that has been noted in other studies.

CR immunoreactive cells were dominant in the inner layers of the DCN, as compared to the outer layer. Faintly stained to darkly labeled cells were present in the AVCN and the PVCN. Similar findings were noted in another study in CBA/CaJ mice (Idrizbegovic et al.). The CR IR appeared to prominently decrease in the AVCN of the cir/ciras compared to the $+/+$ and the $+/$ cir. Matching with the present observation, a decrease in the number of CR immunoreactive cells in the cochlear nucleus of bilaterally deaf C57 mice has been reported (Zettel et al., 2003). Similar studies have noted a decrease in CR expression in the AVCN and the PVCN of guinea pigs, following short-term reversible unilateral deafening (Winsky \& Jacobowitz; Caicedo et al., 1997). However, the cir/cir presents permanent bilateral deafness due to cochlear degeneration and has shown a decrease in the CR IR in the auditory brainstem in general, as well as in the cochlear nucleus. This report is supported by a study conducted to show the long-term effects of permanent bilateral deafening, which also illustrates a decreased expression of $\mathrm{CR}$ in the auditory brainstem in general and in the cochlear nucleus in particular. A decrease of CR IR of the cochlear nucleus, as noted in the present study, may reflect changes in the level of activity of the cochlear nucleus following deafness and concomitant changes in the level of intracellular $\mathrm{Ca} 2+$. This could be the result of downregulation in neuronal activity due to a loss of primary afferents (Tucci et al., 2001). Hence, the loss of the organ of Corti that results in deafness could abolish activity in the VCN, leading to the decrement of CR IR as noted in the cir/cir. The loss of staining of cells in the PVCN part of the cir/cirfurther supports the above statement.

CaBPs has also been noted to be susceptible to changes in the functional activity of the auditory system and may play a role in central auditory neuronal survival during cochlear pathology, as noted in the cir/cir. This is further supported by the localization of CaBPs, such as the CB and $\mathrm{PV}$ in the hair cells and spiral ganglion cells, with staining extending in the longitudinal gradient from the apex (intense) to the base (weakest) of cochlea (Pack \& Slepecky, 1995, Usami et al., 1995). The vertical cells of the DCN receive direct tonotopic projections from the auditory nerve. This might facilitate spectral processing in the VCN, providing immediate frequency-specific inhibition, highlighting the importance of the DCN vertical cells' distribution to the overall inhibitory requirement of the $\mathrm{CN}$ with respect to frequency (Muniak \& Ryugo, 2014). The decrement of the CaBPs IR in the present study might be attributed to functional activity deprivation in the auditory system due to cochlear pathology in the cir/cirmice. 
In conclusion, the decrement in one or more of the $\mathrm{CaBPs}$ in some regions of the auditory nucleus leading to impaired $\mathrm{Ca}^{2+}$ homeostasis could be associated with a neurodegenerative mechanism, which might affect functional and morphological alterations manifesting in the phenotypic behavior of the circling mouse.

\section{ACKNOWLEDGEMENTS}

This study was supported by Research institute for Convergence of biomedical science and technology (302016-020), Pusan National University Yangsan Hospital.

RYU, J. H.; PHRADHAN, J.; KIM, M. J. \& MASKEY, D. Distribución inmunohistoquímica de proteínas de unión a calcio en el complejo nuclear coclear de ratones circulantes. Int. J. Morphol., 39(2):538-547, 2021.

RESUMEN: El término "ratón circulante" se refiere a un modelo animal con sordera, en el que el ratón exhibe hiperactividad, movimientos circulares y movimientos de la cabeza, con características patológicas que incluyen células ganglionares espirales degeneradas en la cóclea, un canal de Rosenthal vacío y la pérdida del órgano de Corti. El complejo nuclear coclear (CN), una parte del circuito cerebral auditivo, es esencial para procesar la información auditiva tanto ascendente como descendente. Considerando la importancia del calcio $\left(\mathrm{Ca}^{2+}\right)$ en la homeostasis de numerosos procesos biológicos, la hipoacusia por daño coclear, por ablación o por defecto genético, podría provocar cambios en la concentración de $\mathrm{Ca}^{2+}$ que pueden desencadenar alteraciones funcionales y estructurales en el circuitoauditivo. Sin embargo, existe poca información de la correlación de la patología del sistema nervioso central (SNC) en ratones circulantes, especialmente del circuito de la víaauditiva y los cambios de $\mathrm{Ca}^{2+}$. Este estudio nvestiga la distribución de proteínas de unión a $\mathrm{Ca}^{2+}(\mathrm{CaBP})$, calbindina D-28k (CB), parvalbúmina $(\mathrm{PV})$ y calretinina $(\mathrm{CR})$ mediante el uso de un método inmunohistoquímico de flotaciónlibre en el $\mathrm{CN}$ del ratón de tiposalvaje $(+/+)$, el ratón heterocigoto $(+/$ cir) y el ratón homocigoto (cir/cir). Se sabe que los CaBP son un factor importante que regula las concentraciones de $\mathrm{Ca}^{2+}$. En comparación con los núcleos cocleares dorsal y ventral de los ratones $+/+$ y $+/$ cir, se observaron disminuciones prominentes de la inmunorreactividad (IR) de CaBPs en los ratonescir/cir en los somas, asícomo en el neuropilo. El presente estudio informa sobre la distribución general y los cambios en la inmunorreactividad de $\mathrm{CaBP}$ en el $\mathrm{CN}$ de ratones cir/cir debido a un defecto auditivo. Estos datos podrían ser útiles para dilucidar morfológicamente los trastornos del SNC y su relación con la inmunorreactividad de CaBP relacionada con los defectosauditivos.

PALABRAS CLAVE: Calretinina; Calbindin D28-k; Complejo Nuclear Coclear; Ratón en círculos; Parvalbúmina.

\section{REFERENCES}

Alvarado, J. C.; Fuentes-Santamaria, V.; Henkel, C. K. \& Brunso-Bechtold, J. K. Alterations in calretinin immunostaining in the ferret superior olivary complex after cochlear ablation. J. Comp. Neurol., 470(1):6379, 2004.

Arundine, M. \& Tymianski, M. Molecular mechanisms of calciumdependent neurodegeneration in excitotoxicity. Cell Calcium, 34(45):325-37, 2003.

Baimbridge, K. G.; Celio, M. R. \& Rogers, J. H. Calcium-binding proteins in the nervous system. Trends Neurosci., 15(8):303-8, 1992.

Caicedo, A.; d'Aldin, C.; Eybalin, M. \& Puel, J. L. Temporary sensory deprivation changes calcium-binding proteins levels in the auditory brainstem. J. Comp. Neurol., 378(1):1-15, 1997.

Caicedo, A.; d'Aldin, C.; Puel, J. L. \& Eybalin, M. Distribution of calciumbinding protein immunoreactivities in the guinea pig auditory brainstem. Anat. Embryol. (Berl.), 194(5):465-87, 1996.

Cant, N. B. \& Benson, C. G. Parallel auditory pathways: projection patterns of the different neuronal populations in the dorsal and ventral cochlear nuclei. Brain Res. Bull., 60(5-6):457-74, 2003.

Cho, K. I.; Lee, J. W.; Kim, K. S.; Lee, E. J.; Suh, J. G.; Lee, H. J.; Kim, H. T.; Hong, S. H.; Chung, W. H.; Chang, K. T.; et al., Fine mapping of the circling (cir) gene on the distal portion of mouse chromosome 9. Comp. Med., 53(6):642-8, 2003.

Cho, K. I.; Suh, J. G.; Lee, J. W.; Hong, S. H.; Kang, T. C.; Oh, Y. S. \& Ryoo, Z. Y. The circling mouse (C57BL/6J-cir) has a 40-kilobase genomic deletion that includes the transmembrane inner ear (tmie) gene. Comp. Med., 56(6):476-81, 2006.

Chung, W. H.; Kim, K. R.; Cho, Y. S.; Cho, D. Y.; Woo, J. H.; Ryoo, Z. Y.; Cho, K. I. \& Hong, S. H. Cochlear pathology of the circling mouse: a new mouse model of DFNB6. Acta Otolaryngol., 127(3):244-51, 2007.

Förster, C. R. \& Illing, R. B. Plasticity of the auditory brainstem: cochleotomy-induced changes of calbindin-D28k expression in the rat. J. Comp. Neurol., 416(2):173-87, 2000.

Franklin, S. R.; Brunso-Bechtold, J. K. \& Henkel, C. K. Bilateral cochlear ablation in postnatal rat disrupts development of banded pattern of projections from the dorsal nucleus of the lateral lemniscus to the inferior colliculus. Neuroscience, 154(1):346-54, 2008.

Franklin, S. R.; Brunso-Bechtold, J. K. \& Henkel, C. K. Unilateral cochlear ablation before hearing onset disrupts the maintenance of dorsal nucleus of the lateral lemniscus projection patterns in the rat inferior colliculus. Neuroscience, 143(1):105-15, 2006.

Friauf, E. Distribution of calcium-binding protein calbindin-D28k in the auditory system of adult and developing rats. J. Comp. Neurol., 349(2):193-211, 1994.

Hack, N. J.; Wride, M. C.; Charters, K. M.; Kater, S. B. \& Parks, T. N. Developmental changes in the subcellular localization of calretinin. $J$. Neurosci., 20(7):RC67, 2000.

Harrison, J. M. \& Irving, R. The organization of the posterior ventral cochlear nucleus in the rat. J. Comp. Neurol., 126(3):391-401, 1996.

Idrizbegovic, E.; Canlon, B.; Bross, L. S.; Willott, J. F. \& Bogdanovic, N. The total number of neurons and calcium binding protein positive neurons during aging in the cochlear nucleus of $\mathrm{CBA} / \mathrm{CaJ}$ mice: a quantitative study. Hear. Res., 158(1-2):102-15, 2001.

Illing, R. B. Activity-dependent plasticity in the adult auditory brainstem. Audiol. Neurootol., 6(6):319-45, 2001.

Kane, E. C. Octopus cells in the cochlear nucleus of the cat: heterotypic synapses upon homeotypic neurons. Int. J. Neurosci., 5(6):251-79, 1973.

Krebs, J. The role of calcium in apoptosis. Biometals, 11(4):375-82, 1998.

Lee, J. W.; Ryoo, Z. Y.; Lee, E. J.; Hong, S. H.; Chung, W. H.; Lee, H. T.; Chung, K. S.; Kim, T. Y.; Oh, Y. S. \& Suh, J. G. Circling mouse, a spontaneous mutant in the inner ear. Exp. Anim., 51(2):167-71, 2002.

Lohmann, C. \& Friauf, E. Distribution of the calcium-binding proteins parvalbumin and calretinin in the auditory brainstem of adult and developing rats. J. Comp. Neurol., 367(1):90-109, 1996. 
Maskey, D.; Kim, M.; Aryal, B.; Pradhan, J.; Choi, I. Y.; Park, K. S.; Son, T.; Hong, S. Y.; Kim, S. B.; Kim, H. G.; et al., Effect of $835 \mathrm{MHz}$ radiofrequency radiation exposure on calcium binding proteins in the hippocampus of the mouse brain. Brain Res., 1313:232-41, 2010.

Mostafapour, S. P.; Cochran, S. L.; Del Puerto, N. M. \& Rubel, E. W. Patterns of cell death in mouse anteroventral cochlear nucleus neurons after unilateral cochlea removal. J. Comp. Neurol., 426(4):561-71, 2000.

Mostafapour, S. P.; Del Puerto, N. M. \& Rubel, E. W. bcl-2 Overexpression eliminates deprivation-induced cell death of brainstem auditory neurons. J. Neurosci., 22(11):4670-4, 2002.

Muniak, M. A. \& Ryugo, D. K. Tonotopic organization of vertical cells in the dorsal cochlear nucleus of the CBA/J mouse. J. Comp. Neurol., 522(4):937-49, 2014

Pack, A. K. \& Slepecky, N. B. Cytoskeletal and calcium-binding proteins in the mammalian organ of Corti: cell type-specific proteins displaying longitudinal and radial gradients. Hear. Res., 91(1-2):119-35, 1995.

Rubel, E. W.; Hyson, R. L. \& Durham, D. Afferent regulation of neurons in the brain stem auditory system. J. Neurobiol., 21(1):169-96, 1990.

Ryugo, D. K. \& Parks, T. N. Primary innervation of the avian and mammalian cochlear nucleus. Brain Res. Bull., 60(5-6):435-56, 2003.

Syka, J. Plastic changes in the central auditory system after hearing loss, restoration of function, and during learning. Physiol. Rev., 82(3):60136, 2002.

Tucci, D. L.; Cant, N. B. \& Durham, D. Effects of conductive hearing loss on gerbil central auditory system activity in silence. Hear. Res., 155(12):124-32, 2001

Usami, S.; Shinkawa, H.; Inoue, Y.; Kanzaki, J. \& Anniko, M. CalbindinD28K localization in the primate inner ear. ORL J. Otorhinolaryngol. Relat. Spec., 57(2):94-9, 1995.

Winsky, L. \& Jacobowitz, D. M. Effects of unilateral cochlea ablation on the distribution of calretinin mRNA and immunoreactivity in the guinea pig ventral cochlear nucleus. J. Comp. Neurol., 354(4):564-82, 1995.

Yew, D. T.; Luo, C. B.; Heizmann, C. W. \& Chan, W. Y. Differential expression of calretinin, calbindin D28K and parvalbumin in the developing human cerebellum. Dev. Brain Res., 103(1):37-45, 1997.

Zettel, M. L.; Carr, C. E. \& O'Neill, W. E. Calbindin-like immunoreactivity in the central auditory system of the mustached bat, Pteronotus parnelli. J. Comp. Neurol., 313(1):1-16, 1991

Zettel, M. L.; O'Neill, W. E.; Trang, T. T. \& Frisina, R. D. The effects of early bilateral deafening on calretinin expression in the dorsal cochlear nucleus of aged CBA/CaJ mice. Hear. Res., 183(1-2):57-66, 2003.

Zirpel, L.; Lachica, E. A. \& Lippe, W. R. Deafferentation increases the intracellular calcium of cochlear nucleus neurons in the embryonic chick. J. Neurophysiol., 74(3):1355-7, 1995.

\section{Corresponding author: \\ Myeung Ju Kim, M.D., Ph.D. \\ Department of Anatomy \\ Dankook University \\ College of Medicine \\ San\#29, Anseo-Dong, Cheonan \\ Chungnam \\ SOUTH KOREA}

E-mail: mjukim99@dankook.ac.kr

\author{
Corresponding author: \\ Dhiraj Maskey, Ph.D. \\ NeuroVIS \\ Cheonan SB Plaza, Jiksan-ro \\ Seobuk-gu, Cheonan-si \\ Chungnam \\ SOUTH KOREA
}

Email: dhiraj_mask@yahoo.com

Received: $14-10-2020$

Accepted: 21-11-2020 